\title{
Heavy Metals in Sediment from Alvarado Lagoon System in Veracruz, México
}

\author{
María del Refugio Castañeda-Chávez, Fabiola Lango-Reynoso, Gabycarmen Navarrete- \\ Rodríguez
}

Tecnológico Nacional de México /Instituto Tecnológico de Boca del Río, Carretera Veracruz, Boca del Río, Veracruz, México

\begin{abstract}
Heavy metals are one of the main sources of pollution in sediment in coastal lagoons in Mexico. The presence of metals in sediments of these aquatic bodies, are an indicator that allows us to know the environmental quality of ecosystems and the risk it poses to public health. This, due to consumption of aquatic organisms that have direct contact with the sediment when inhabiting the bottom of the lagoon system. The objective of this research was to determine the concentration of $\mathrm{Pb}, \mathrm{Cd}, \mathrm{Cu}, \mathrm{Cr}$ and Co in the Alvarado lagoon complex in Veracruz, Mexico. Sediments of 41 sampling stations were analyzed. Sediment digestion for the analysis of heavy metals was carried out in a CEM Microwave Accelerated Reaction System, Model MARS 5®. The concentrations levels of the metals were analyzed by atomic absorption through flame spectrophotometry on a Thermo Cientific 3500 Model AA Ice System. The presence of the five metals were found in all 41 analyzed stations. The Co presented the maximum concentration with $9.53 \mu \mathrm{g} g-1$. Concentrations were within the limits established by international legislation with the exception of $C d$. However, continuous analyzes should be carried out in this study area to ensure the environmental quality of sediments as a final deposit site for persistent organic pollutants. The above as a result of different productive activities that impact this area of study.
\end{abstract}

Keywords - Affinity and particle size, bioavailability, risk, public health, temporality.

\section{INTRODUCTION}

Heavy metals and trace elements are incorporated into aquatic ecosystems from natural and anthropogenic sources [1]. These are considered as one of the most important environmental pollutants due to their toxicity and persistence, as well as being little biodegradable elements that accumulate in the tissues of aquatic organisms. They are also responsible for contributing and generating biomagnification processes [1, 2]. Research showed the presence of these elements in aquatic ecosystems such as lagoon systems of the Gulf of Mexico $[3,4,5,6]$.
In coastal lagoons, pollutants undergo a series of transformations, such as precipitation, flocculation and sedimentation, before finally reaching the sea. However, these processes may lead to increased toxicity of these compounds, as well as increasing their residence time in the water column and their toxicity in organisms inhabiting these ecosystems [5,6].

In the process of transporting heavy metals to the sea, they suffer different physical and chemical transformations, such as precipitation from the water column, sedimentation and final adsorption, in sediments that make them bioavailable for aquatic life forms [7].

Therefore, an analysis of sediments and aquatic biota is an efficient way to evaluate hydrophobic pollutants present in these bodies; which also have a low solubility in water, high solubility in lipids and a strong tendency to absorb organic matter in soil and sediment [8]. Metals produce severe damage when ingested at concentrations greater than the tolerance limits of organisms [7]. Heavy metals are contaminants that accumulate in organisms that inhabit sediments and, that being the case, can be transferred to higher trophic levels, through the food chain. The above reflects a risk to public health $[1,6,7,9]$. Therefore, it is necessary to know the environmental quality of sediments given its effect on various trophic levels and the transport of pollutants. The objective of this work was to determine the concentration of heavy metals in sediment of the Alvarado lagoon system, Veracruz, Mexico.

\section{MATERIALS AND METHODS}

\subsection{Study area}

The Alvarado Lagoon System (CLA) is located southeast of the state of Veracruz at coordinates $18^{\circ} 44^{\prime} 00$ and $18^{\circ} 52^{\prime} 15$ North Latitude and 95 $44^{\prime} 00$ and $95^{\circ} 57^{\prime} 00$ Western Longitude [10]. This system is located $70 \mathrm{~km}$ southeast of the port of Veracruz and is at an elevation of $10 \mathrm{~m}$ above sea level $[11,12]$.

This lagoon-estuarine system is composed of more than 100 brackish coastal lagoons and seasonally flooded areas, among which are the lagoon bodies of Alvarado, Camaronera and Buen País, as well as interior lagoons of 
Pajarillos, Popuyeca, El embarcadero, among others. (Figure 1). The entire lagoon body has an extension of 6200 ha and a maximum width of $4.5 \mathrm{~m}[12,13]$. The main contributions of water to the system are the Papaloapan, Acula, Blanco and Limón rivers [14].

\subsection{Collection and treatment of samples}

Sediment sampling was performed during dry season from April to June, samples were collected at 41 stations to determine $\mathrm{Pb}, \mathrm{Cd}, \mathrm{Cu}, \mathrm{Cr}$ and $\mathrm{Co}$. Samples were collected with a dredge and stored in polyethylene bags to be transported to laboratory at temperatures of $5^{\circ} \mathrm{C}$, then these were preserved in freezing. The collected samples were lyophilized with a Thermo Savant Modulyo D-114 kit for 72 hours at $-49^{\circ} \mathrm{C}$ and a vacuum pressure of $36 \times 10-3$ mbar. These were stored in sealed bags, milled with a mortar and pestle to a fine particle size, then homogenized with No. 30 sieve with a $595 \mu \mathrm{m}$ aperture.

\subsection{Analysis of sediment samples}

The sediment digestion prior to analysis of heavy metals was performed in a CEM Microwave Accelerated Reaction System, Model MARS 5®, in which samples were submitted to a digestion process according to the EPA method [15].

To perform digestion on microwave equipment, $0.5 \mathrm{~g}$ of the samples were taken, placed in an HP-500 Teflon beaker to which was added a $9.0 \mathrm{ml}$ volume of $90 \%$ reactive grade nitric acid. This process was performed at a temperature of $190^{\circ} \mathrm{C}$. Each group was accompanied with a blank sample and a reference control. After digestion was completed, samples were filtered with the support of a Nalgene bottle with Millipore ${ }^{\circledR}$ nitrocellulose $0.45 \mu \mathrm{m}$ filters. The resulting filtrate was then placed in a $25 \mathrm{ml}$ volumetric flask to be calibrated with Milli-Q® quality deionized water. The already calibrated samples were transferred to amber bottles and stored at a temperature of $4^{\circ} \mathrm{C}$ for subsequent quantification of the concentrations of $\mathrm{Cd}, \mathrm{Cu}, \mathrm{Cr}$ and $\mathrm{Co}$. Those concentrations were determined by atomic absorption by flame spectrophotometry on a Thermo Cientific 3500 Model AA Ice System (ThermoCientific ${ }^{\circledR}$, China) and $\mathrm{Pb}$ was determined by the $220 \mathrm{Z}$ Graphite Furnace. Analytical determination of heavy metals previously mentioned were performed according to the technique described according to NOM117-SSA1-1994 [16].

\subsection{Statistic analysis}

Concentrations of heavy metals in sediment were analyzed using the software Statistica 7.0 (StatSoft, Inc. Tulsa, USA), using the One-way Analysis of Variance (ANOVA) and Tukey Multiple Comparison test.

\section{RESULTS AND DISCUSSION}

$\mathrm{Pb}, \mathrm{Cd}, \mathrm{Cu}, \mathrm{Cr}$ and $\mathrm{Co}$ presence was detected in all analyzed stations of the Alvarado Lagoon system (Table 1). Maximum concentrations of metals presented the following distribution: $\mathrm{Co}(9.53)>\mathrm{Cr}$ (7.32)> $\mathrm{Cd}$ (5.27)> $\mathrm{Cu}(5.18)>\mathrm{Pb}\left(2.30 \mu \mathrm{g} \mathrm{g}^{-1}\right)$. Variations in concentrations of metals depend on their physical and chemical properties, since they can be mobilized and transported in the ecosystem, as well as represent a risk in the quality of the same $[1,17]$. However, there were no statistically significant differences $(p>0.05)$ between concentrations of heavy metals in the stations and metals analyzed (Figure 2), except $\mathrm{Cr}$ at station number $28\left(7.210 \pm 0.155 \mu \mathrm{g} \mathrm{g}^{-1}\right)$.

\subsection{Lead (Pb)}

$\mathrm{Pb}$ concentrations obtained in this research showed significant differences to studies reported by previous investigations in the area, with a mean value of $27.49 \pm$ $13.65 \mu \mathrm{g} \mathrm{g}^{-1}$ [18]. Likewise, no statistically significant differences were obtained in the sampling stations (Table $3)$.

Regarding Sadiq's permissible limits (1992) with $5 \mu \mathrm{g} \mathrm{g}^{-1}$ (Table 1), mean and maximum concentrations obtained in Alvarado $\left(0.696 \pm 0.609\right.$ and $\left.2.3 \mu \mathrm{g} \mathrm{g}^{-1}\right)$ did not exceed the reference value (Table 2). However, presence of $\mathrm{Pb}$ in sediment highlights the potential hazard to aquatic organisms inhabiting lagoon systems [19].

\subsection{Cadmium (Cd)}

Maximum concentration of $\mathrm{Cd}$ was $5.27 \mu \mathrm{g} \mathrm{g}^{-1}$, while mean value was $0.858 \pm 1.019 \mu \mathrm{g} \mathrm{g}^{-1}$, the latter value being within the reference range reported in uncontaminated sediment of 1 and $1.2 \mu \mathrm{g} \mathrm{g}^{-1}$ [ 20, 21], (Table 2). This contrasts with what was reported in the Paliza River located in the state of Campeche, where $\mathrm{Cd}$ values exceeded these established limits [1].

The existence of $\mathrm{Cd}$ in the environment is to draw attention, because its high degree of toxicity and its presence in sediments is due to a completely anthropogenic origin by activities where this metal has been used [1].

\subsection{Copper $(\mathrm{Cu})$}

Concentrations obtained for $\mathrm{Cu}$ in this study can be considered as low compared to other studies in lagoon sediments, in which values of 41.13 and $18 \mu \mathrm{g} \mathrm{g}^{-1}$ were obtained $[22,8]$. As well as the mean value reported for the Alvarado lagoon with $17.49 \pm 4.09 \mathrm{\mu g} \mathrm{g}^{-1}$ [18].

Variations in $\mathrm{Cu}$ levels have been associated with particle size, where finer sediment particles such as clay had a high affinity to sediment and provide higher ionic absorption and attraction. Therefore, the persistence of $\mathrm{Cu}$ deposited in the sediments contributes to these being bioavailable for 
those organisms whose eating habits make them susceptible to the ingestion of these contaminants [1, 23].

\subsection{Chromium (Cr)}

Mean concentration of $\mathrm{Cr}$ in the present study was $2.161 \pm$ $1.899 \mu \mathrm{g} \mathrm{g}^{-1}$ (Table 2). This value was lower than that reported in an earlier research also for the Alvarado lagoon system in 2005 with a value of $13.75 \pm 9.04 \mu \mathrm{g} \mathrm{g}^{-1}$ [18]. Previous concentrations and those reported in this study had values below the allowable limit of $20 \mu \mathrm{g} \mathrm{g}^{-1}$ (Table 2) for coastal sediments [19].

Variations in concentrations of this metal may be due to the fact that $\mathrm{Cr}$ is characterized by showing a regional transport pattern due to deposition and erosion regimes [24].

\subsection{Cobalt (Co)}

Maximum concentration with respect to the other metals corresponded to Co with $9.53 \mu \mathrm{g} \mathrm{g}^{-1}$, this value exceeded the concentrations reported for Castillero lagoon in Venezuela with values of 1.14 and $6.92 \mu \mathrm{g} \mathrm{g}^{-1}$ [24]. Other research stated, also in sediment, values of $10.10 \pm 1.68 \mu \mathrm{g}$ $\mathrm{g}^{-1}$ during autumn, while in winter it was $19.23 \pm 2: 47 \mu \mathrm{g}$ $\mathrm{g}^{-1}[25]$.

Higher concentration of Co may be related to its characteristics, being a biologically important metal naturally present in the environment. Cobalt may enter the environment from both natural sources and human activities. It occurs naturally in soil, rock, air, water, plants, and animals. It may enter air and water, and settle on land from windblown dust, and enter the surface of water through the runoff when rainwater runs through the ground [26]. Although this is an essential metal for organisms in low concentrations, whereas at high concentrations may be toxic [27]. However, it should also be highlighted that mean concentration presented a value of $0.804 \pm 1.206 \mu \mathrm{g} \mathrm{g}^{-1}$. It should be noted that there is little research to compare the concentration of Co in lagoon sediments and there are no permissible limits on its concentration (Table 2). Only ATSDR [28] established that concentration of $\mathrm{Co}$ in soil varies considerably between 1 and $40 \mu \mathrm{g} \mathrm{g}^{-1}$, with an average of $7 \mu \mathrm{g} \mathrm{g}^{-1}$. The above mentioned highlights the scarce existing knowledge on the biogeochemical behavior of cobalt in aquatic systems [19, 29, 30, 31].

\section{CONCLUSION}

Sediments in coastal lagoons constitute a site of deposit of heavy metals, which can form associations with the texture of the sediment and with other metals. It is therefore necessary to take samples continuously and with greater depth. This, as a needed action for better control of $\mathrm{Pb}, \mathrm{Cd}$, $\mathrm{Cu}, \mathrm{Cr}$ and $\mathrm{Co}$. Apart from having the purpose of www.ijeab.com preserving the coastal environment, defining policies and mitigating agricultural production and energy generation actvities. And thus avoid greater impact to the environment.

Regarding the comparison with reference values reported for uncontaminated sediments and adverse effects to aquatic biota, it was observed that maximum concentration of Cd (1 $\mu \mathrm{g} g-1)$ exceeded this value. However, the rest of the metals $\mathrm{Pb}, \mathrm{Cu}$ and $\mathrm{Cr}$ presented concentrations lower than this reference with 5,10 and $20 \mu \mathrm{g}$ g-1, respectively. In the case of Co there is no specific limit of reference, but given the biospecific character of this metal, results in this research presented values similar to those reported in other investigations.

There are no clear criteria to establish contamination by heavy metals of a sediment, because its composition can be very varied due to the influence of type of granulometry and the content in organic matter mainly. It is also highlighted in this study that effective control over the presence of pollutants in coastal environment such as rivers and lagoons in Mexico can be associated with industrial and urban growth. The presence of these pollutants and the lack of national regulation represent an environmental and public health risk in Mexico, which has made it necessary to turn to international standards.

\section{ACKNOWLEDGEMENTS}

WE WOULD LIKE TO THANK THE CONSOLIDATED ACADEMIC GROUP “CIENCIAS ACUÍCOLAS Y PESQUERAS” BY PRODEP: ITBOR-CA-2, AND TO FISHING COOPERATIVES OF ALVARADO , VERACRUZ FOR THEIR SUPPORT TO CARRY OUT THE SAMPLING.

\section{REFERENCES}

[1] C. Montalvo; C. Aguilar; L.E. Amador; J. Cerón; R. Cerón; F. Anguebes and A.V. Cordova. Metal Contents in Sediments ( $\mathrm{Cd}, \mathrm{Cu}, \mathrm{Mg}, \mathrm{Fe}, \mathrm{Mn})$ as Indicators of Pollution of Palizada River, Mexico. (2014), Environment and Pollution, 3(4): 89-98.

[2] INVEMAR. Informe del Estado de los Ambientes Marinos y Costeros en Colombia año 2001. INVEMAR. (2002), Serie de Publicaciones Periódicas, No 8. pp. 250.

[3] F. Lango-Reynoso, M. R. Castañeda-Chávez, C. Landeros-Sánchez, I. Galavíz-Villa, G. NavarreteRodríguez, and $\mathrm{A}$. Soto-Estrada. $\mathrm{Cd}, \mathrm{Cu}, \mathrm{Hg}$ and $\mathrm{Pb}$, organochlorine pesticides in commercially important benthic organisms from coastal lagoons along $\mathrm{SW}$ Gulf of Mexico. (2013), Agricultural Science, 1: 6380. http://dx.doi.org/10.12735/as.v1i1p63

[4] M.R. Castañeda-Chávez, G. Navarrete-Rodríguez, F. Lango-Reynoso, I. Galaviz-Villa, and C. Landeros- 
Sánchez. 2014. Heavy Metals in Oysters, Shrimps and Crabs from Lagoon Systems in the Southern Gulf of México. Journal of Agricultural Science, 6(3): 108-117.

[5] D.O. Leyva-Cardoso., G. Ponce-Vélez, A.V. Botello and G. Díaz-González. (2003). Persistent organochlorine pesticides in coastal sediments from Petacalco Bay, Guerrero, México. Bulletin of Environmental Contamination and Toxicology, 71: 1244-1251.

[6] R.C. Palmerín, G. Ponce-Velez, and A.V. Botello; Evaluación de plaguicidas organoclorados en sedimentos y organismos filtradores de la laguna de Alvarado, Veracruz, México. en Contaminación e Impacto Ambiental: Diagnóstico y Tendencias A. V. Botello, J. Rendón von Osten, J. Benítez, \& G. GoldBouchot (Eds.), Golfo de México. (3rd ed., México D. F.: UAC, UNAM-ICMYL, CINVESTAV-Unidad Mérida. (2014). pp. 285-308.

[7] C.A. Aguilar, C. Montalvo, L.A. Rodríguez, J.G. Cerón, and R.M. Cerón. American oyster (Crassostrea virginica) and sediments as a coastal zone pollution monitor by heavy metals. (2012), Int. J. Environ. Sci. Technol, 9:579-586.

[8] USGS. Pesticides in stream sediment and aquatic biota. Current Understanding of Distribution and Major Influences. (2017), Pesticide National Synthesis Project. [Accessed January 20, 2017] https://water.usgs.gov/nawqa/pnsp/pubs/fs09200/fs09 200.pdf

[9] N. Bortey-Sam., S.M.M. Nakayama., Y. Ikenaka., O. Akoto., E. Baidoo., Y.B. Yohannes., H. Mizukawa., and M. Ishizuka. Human health risk from metals and metalloid via consumption of food animals near gold mines in Tarkwa, Ghana: Estimation of the daily intakes and target hazard quotients (THQ). (2015), Ecotoxicology and Environmental Safety, 111: 160167.

[10] A. Resendez-Medina. Estudio de los peces de la laguna de Alvarado, Veracruz, México. (1973), Rev. Soc. Mex. Hist. Nat, 34: 183-276.

[11]M. Reguero., and A. García-Cubas. Moluscos de la Laguna de Alvarado, Veracruz: Sistemática y Ecología. [En línea]. (1989), Instituto de Ciencias del Mar y Limnología. UNAM. [Accessed June 5, 2012]. http://biblioweb.dgsca.unam.mx/cienciasdelmar /instituto/1989-2/ articulo347.html

[12] Carta Nacional Pesquera. Ecosistemas lagunares costeros. Diario Oficial de la Federación 15 de Marzo de

2004.

http://www.conapesca.sagarpa.gob.mx/wb/cona/cona _parte_4_[Consultado el 25 de Enero de 2017]. (2004).
[13]E. Portilla-Ochoa. Ficha informativa de los humedales de Ramsar (IFR). Sistema Lagunar Alvarado. http://www.ramsar.org. Accessed March 3, 2016. (2003).

[14] A.D. Vázquez-Lule., M.T. Rodríguez-Zúñiga and P. Ramírez-García. Caracterización del sitio de manglar Sistema Lagunar de Alvarado, Veracruz. Sitios de manglar con relevancia biológica y con necesidades de rehabilitación ecológica. CONABIO, México, D.F. (2009).

[15]EPA. Method 3052. Microwave assisted acid digestion of siliceous and organically based matrices. United States. (1996). pp. 32

[16] Diario Oficial de la Federación. 1994. NOM-117SSA1-1994. Bienes y servicios. método de prueba para la determinación de cadmio, arsénico, plomo, estaño, cobre, fierro, zinc y mercurio en alimentos, agua potable y agua purificada por espectrometría de absorción atómica.

[17]R.A. Sutherland., and M.G. Tack, F. Determination of $\mathrm{Al}, \mathrm{Cu}, \mathrm{Fe}, \mathrm{Mn}, \mathrm{Pb}$ and $\mathrm{Zn}$ in certified reference materials using the optimized BCR sequential extraction procedure. (2002), Analytica Chimica Acta, 454, 249-257. http://dx.doi.org/10.1016/S00032670(01)01553-7.

[18]P. Guzmán-Amaya., S. Villanueva, F. and A. Botello, V. Metales en tres lagunas costeras del estado de Veracruz. In Golfo de México Contaminación e Impacto Ambiental: Diagnostico y Tendencias. 2da Edición, A. V. Botello, J. Rendón von Osten, G. Gold Bouchot y C. Agraz Hernández (Eds.). Univ. Autón. de Campeche, Univ. Nal. Autón. de México, Instituto Nacional de Ecología. (2005). pp. 361 - 372.

[19] A. Márquez., W. Senior., G. Martínez., J. Castañeda., and A. González. Concentraciones de metales en sedimentos y tejidos musculares de algunos peces de la laguna de Castillero, Venezuela. (2008), Revista Científica, FCV-LUZ, 18(2): 121 - 133.

[20] M. Sadiq. Heavy metals. in Toxic metal chemistry in marine environments. Marcel Dekker, Inc., New York. (1992). pp. 390.

[21]E.R. Long., D.D. MacDonald., S.L. Smith., and F.D. Calder. Incidence of adverse biological effects within ranges of chemical concentrations in marine and estuarine sediments. (1995), Environ. Management, 19 (1): 81-87.

[22] A. Márquez., W. Senior., I. Fermín., G. Martínez., J. Castañeda. and J. González. Cuantificación de las concentraciones de metales pesados en tejidos de peces y crustáceos de la laguna de Unare, estado Anzoátegui, Venezuela. (2008), Revista Científica, FCV-LUZ, 18(1):1-14. 
[23] J.A. Villaescusa., E.A. Gutiérrez., and G. Flores. Heavy metals in the fine fraction of coastal sediments from Baja California (Mexico) and California (USA). (2000), Environmental Pollution, 108: 453-462. http://dx.doi.org/10.1016/S0269-7491(99)00222-5.

[24] M.V. Fuentes H,. Metales trazas en los sedimentos superficiales de la Laguna de Chacopata, Estado Sucre, Venezuela. (1999), Scientia, 14(1): 97-116.

[25] A.S. Abouhend., and K.M. El-Moselhy. Spatial and Seasonal Variations of Heavy Metals in Water and Sediments at the Northern Red Sea Coast. (2015), American Journal of Water Resources, 3(3): 73-85. DOI: 10.12691/ajwr-3-3-2.

[26] M. Kobayashi., S. Shimizu. Cobalt proteins. (1999), Europ. J. of. Biochem, 261: 1-9.

[27] R.B. Clark. 1992. Marine pollution. Claredon, Oxford.
[28] ATSDR. Cobalto. Agencia para Sustancias Tóxicas y el Registro de Enfermedades. Departamento de Salud y Servicios Humanos de los EE.UU. (2004). pp. 12

[29] M. Ellwood., and C. Van Den Berg. Determination of organic complexation of cobalt in seawater by cathodic stripping voltammetry. (2001), Mar. Chem, 75: 33-47.

[30]Canadian Sediment Quality Guidelines. 2017. Canadian Sediment Quality Guidelines for the Protection of Aquatic Life. Consultado el 10 de Abril de 2017. http://ceqg-rcqe.ccme.ca/download/en/233

[31]L. Rojas de Astudillo., I. Chang Yen and I. Bekele. Heavy metals in sediments, mussels and oysters from Trinidad and Venezuela. (2005), Rev. Biol. Trop, 53(1): 41-53.

Table.1: Comparison of mean concentrations of metals in sediment $\left(\mu \mathrm{g}^{-1}\right)$ of the Alvarado lagoon complex, Veracruz, Mexico.

\begin{tabular}{|l|l|l|l|l|l|}
\hline & \multicolumn{1}{c|}{ Pb } & \multicolumn{1}{c|}{ Cd } & \multicolumn{1}{c|}{ Cu } & \multicolumn{1}{c|}{ Cr } & \multicolumn{1}{c|}{ Co } \\
\hline Maximum & 2.3 & 5.27 & 5.18 & 7.32 & 9.53 \\
\hline Minimum & 0.02 & 0.01 & 0.02 & 0.10 & 0.020 \\
\hline Mean & $0.696 \pm 0.609$ & $0.858 \pm 1.019$ & $0.688 \pm 0.876$ & $2.161 \pm 1.899$ & $0.804 \pm 1.206$ \\
\hline
\end{tabular}

Table.2: Heavy metals permissible limits in coastal sediments $\left(\mu \mathrm{g} \mathrm{g}^{-1}\right)$.

\begin{tabular}{|c|c|c|c|c|c|l|}
\hline \multirow{2}{*}{ Metal } & \multicolumn{2}{|c|}{ Canadien guidelines (2017) } & \multicolumn{2}{|c|}{ NOAA Guidelines } & \multirow{2}{*}{ Sadiq (1992) } & \multirow{2}{*}{ Long et al., (1995) $^{\mathbf{6}}$} \\
\cline { 2 - 5 } & ERL $^{\mathbf{1}}$ & ERM $^{\mathbf{2}}$ & TEL $^{\mathbf{3}}$ & PEL $^{\mathbf{4}}$ & & \\
\hline Pb & 46.7 & 218 & 30.2 & 112 & 5 & 46.7 \\
\hline $\mathbf{C d}$ & 1.2 & 9.6 & 0.7 & 4.2 & 1 & 1.2 \\
\hline $\mathbf{C u}$ & 34 & 270 & 18.7 & 108 & 10 & 34 \\
\hline $\mathbf{C r}$ & 81 & 370 & 52.3 & 160 & 20 & 81 \\
\hline $\mathbf{C o}$ & -- & -- & -- & -- & -- & -- \\
\hline
\end{tabular}

Source: [30, 31, 20, 21]. Abbreviations: ${ }^{1}$ Effects range low (ERL); ${ }^{2}$ Effects range median (ERM); ${ }^{3}$ Threshold Effect Level (TEL); ${ }^{4}$ Probable Effect Level (PEL); ${ }^{5}$ Reference value for uncontaminated sediment; ${ }^{6}$ Value in sediment that produces biological effects; -- Not established. 


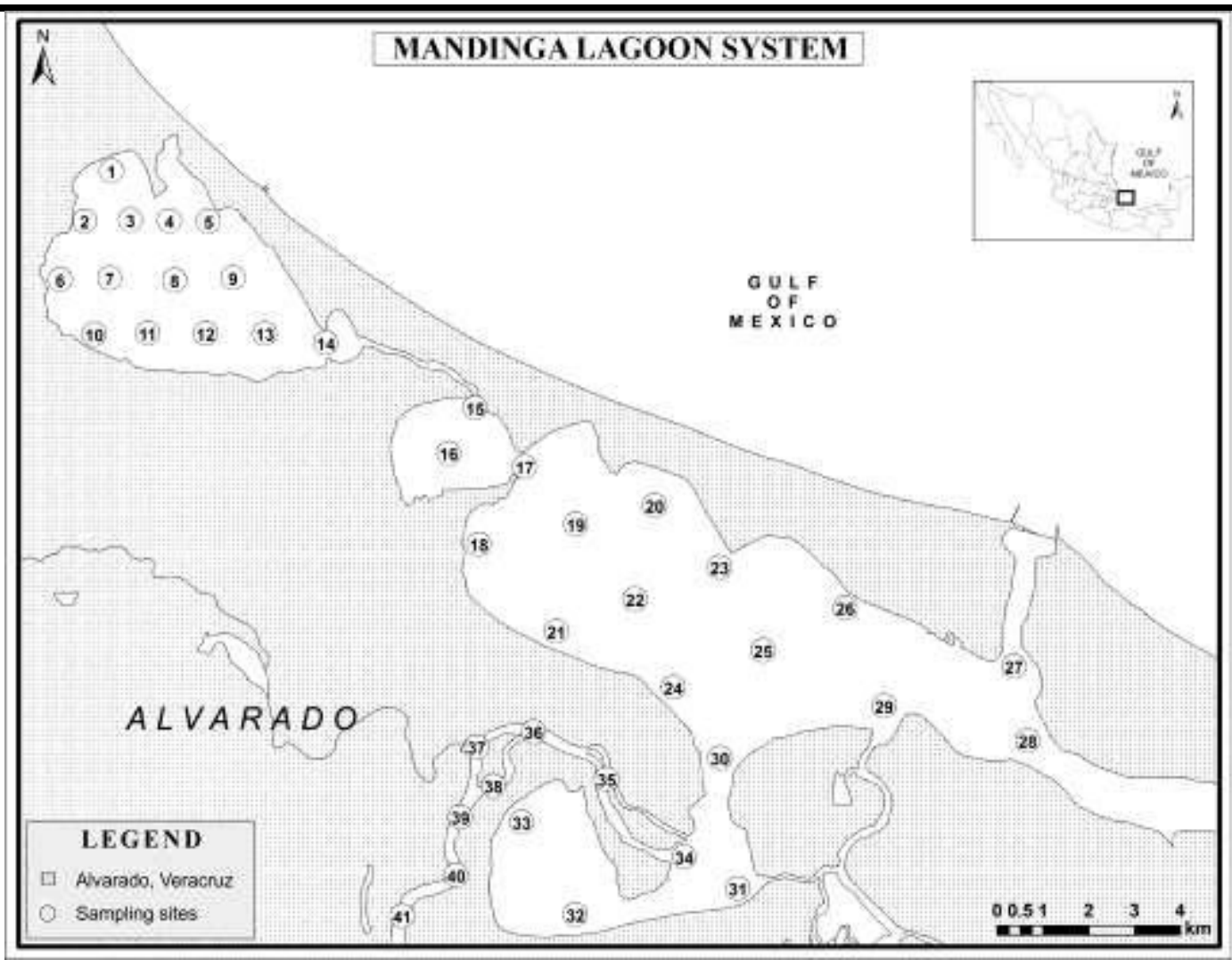

Fig.1: Sampling stations in the Alvarado lagoon system, Veracruz.

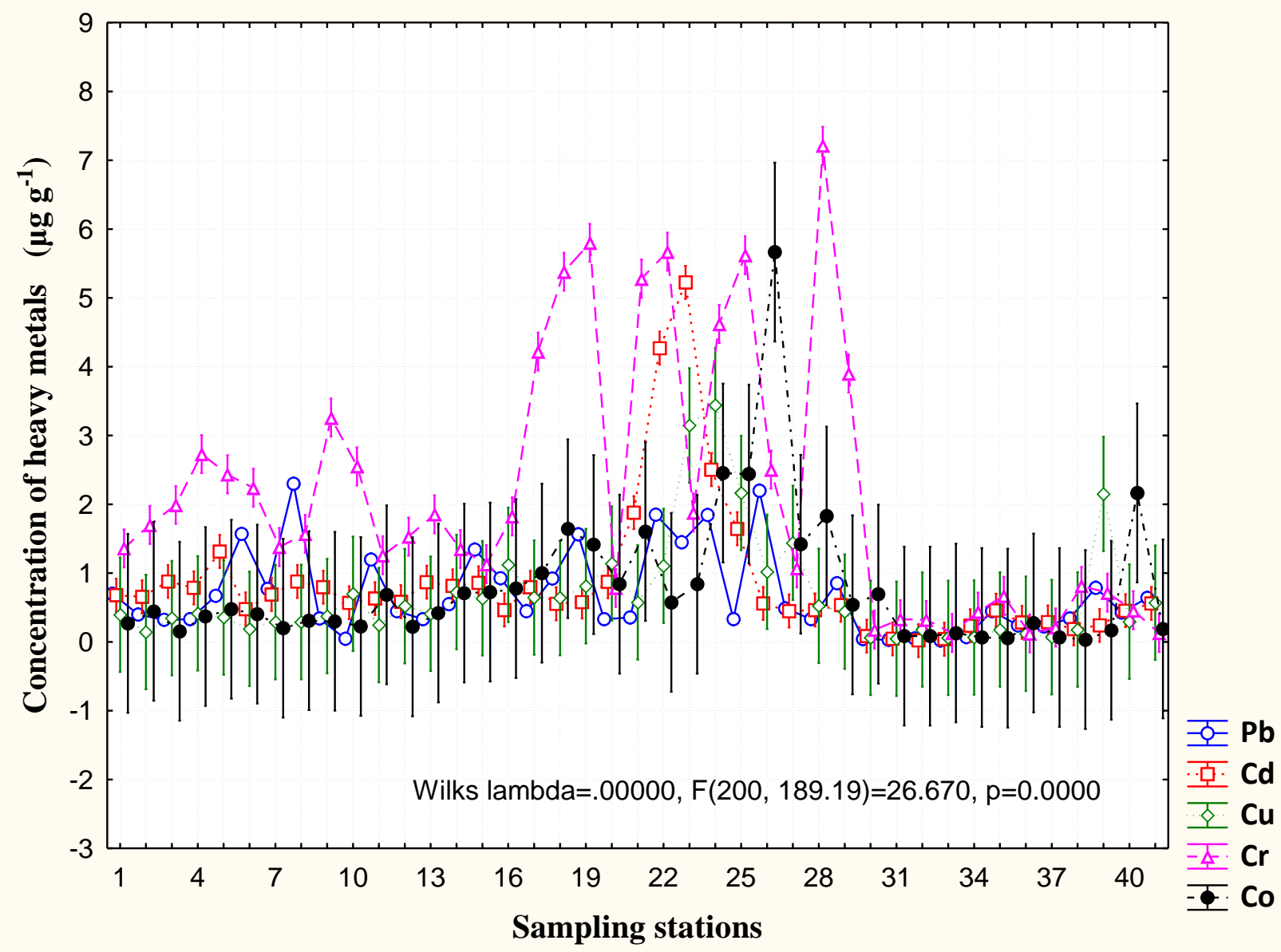

Fig.2: Concentration of heavy metals in sediment $\left(\mu g \mathrm{~g}^{-1}\right)$ of the Alvarado lagoon complex, Veracruz, México www.ijeab.com 